\title{
The effect of CIPPA instructional model and inquiry method on nursing students' achievement and scientific attitude
}

\author{
Suwanida Anjirawaroj a,1,* \\ a Faculty of Liberal Art and Education, Pathumthani University, 140 Moo 4, Tiwanon Road, Baan Klang, Muang District, \\ Pathum Thani 12000 Thailand \\ 1 Suwanidaptu@gmail.com \\ ${ }^{*}$ Corresponding author
}

\begin{tabular}{|c|c|}
\hline ARTICLE INFO & ABSTRACT \\
\hline $\begin{array}{l}\text { Article history } \\
\text { Received March 11, } 2020 \\
\text { Revised June 06, } 2020 \\
\text { Accepted June } 30,2020 \\
\text { Published July 21, } 2020 \\
\text { Keywords } \\
\text { CIPPA } \\
\text { Nursing students } \\
\text { Scientific achievement } \\
\text { Scientific attitude }\end{array}$ & $\begin{array}{l}\text { A good comprehension in the both theoretical and practical principles aspects is crucial } \\
\text { for nursing students to achieve scientific achievement and attitude. The purpose of this } \\
\text { research was observing the effect of CIPPA instructional model on nursing students' } \\
\text { scientific achievement and attitude. The population of this study was } 110 \text { nursing students } \\
\text { who were in first semester of the academic year } 2018 / 2019 \text {. The samples were selected } \\
\text { and divided equally into two groups by using cluster random sampling technique. The first } \\
\text { group was taught by using inquiry method instructional model while the other was taught } \\
\text { using CIPPA instructional model. The research instruments were three plans of inquiry } \\
\text { method and CIPPA instructional model, Biology for Health Science Achievement and } \\
\text { Students' Scientific Attitude tests. The data analysis techniques used mean, standard } \\
\text { deviation, and t-test. The study results showed that there was no significant difference } \\
\text { between the two groups observed in both scientific achievement [t } t(53)=0.42, p=.81] \\
\text { and attitude [t(53) }=1.12, p=.313] \text {. Interestingly, albeit that students' perseverance and } \\
\text { responsibility reached the highest score yet their rationality placed in the lowest level. } \\
\text { Hence, more intensive and detail attention need to be given in all aspects of students' } \\
\text { scientific attitude. }\end{array}$ \\
\hline
\end{tabular}

How to cite: Anjirawaroj, S. (2020). The effect of CIPPA instructional model and inquiry method on nursing students' achievement and scientific attitude. JPBI (Jurnal Pendidikan Biologi Indonesia), 6(2), 181-188. doi: https://doi.org/10.22219/jpbi.v6i2. 11496

\section{INTRODUCTION}

Science has a very important role in today's and future world society. Science deals with everyone in everyday life and in various works and technologies (Combi, 2016; Dufva \& Dufva, 2019; Severinghaus, 2014). Tools and appliances that humans use to facilitate life and work are all closely related to science (Garcia, 2000; Ingthorsson, 2013; Ramirez \& Cayón-Peña, 2017; Tal \& Dierking, 2014). Science helps humans to develop their way of thinking, namely thinking logically, thinking creatively, analyzing, and thinking critically (Almeida \& Franco, 2011; Sellars et al., 2018; Spector \& Ma, 2019; Uluçınar \& Arı, 2019). Science helps people to practice their skills to solve problems systematically and make decisions using a variety of appropriate and accurate information. 
Science is a culture of the modern world which is a knowledge-based society (Afgan \& Carvalho, 2010; Carrillo, 2015; Phillips, Yu, Hameed, \& El Akhdary, 2017; Vali, 2013; Wang, 2018). People need to learn science in order to have knowledge and understand of natural rain and man-made technology as well as be able to apply knowledge with reason, creatively and morality (The Ministry of Education of Thailand, 2008). Consistent with the vision of science learning in accordance with the standard curriculum of the basic education that learning science is a lifelong learning since scientific knowledge is a story about the ever-changing world's nature. Everyone must learn to apply learning results in their lives, careers, and the preservation of natural resources and the environment sustainably (The Ministry of Education Thailand, 2001). Related to the topics, the report from the achievement that appears in the course report of biology for health sciences of the first year nursing students at Pathumthani University-Thailand found that some students have a low average academic achievement. This problem should get a proper solution. It is necessary to have student-centered teaching and learning, which encourages students to learn theory as well as action.

One instructional model that has the potential to overcome this problem is the CIPPA instructional model. The teaching and training for thinking skill by using various instructional models and processes focusing on thinking such as CIPPA instructional model by Tissana Kammanee (Ariratana, 2010). CIPPA was focus on the learner as a center in learning activities (Hengchaiyo, 2017) or a student-centered learning (Klinbumrung, Tansriwong, \& Akatimagool, 2015). CIPPA was the one perfect model to be used because it is a learner-centered model which open the opportunities for students to participate in every steps of learning process and students are motivated to think and explore the knowledge by themselves (Swekwi \& Songkampol, 2019). CIPPA provide the children freedom of learning, in which they had a chance to study themselves, as well as the collaboration that they learned together as a group or team (Thita \& Ariya, 2020). Therefore, it helps the learners to learn skills in terms of content, principles, theory, and practice. Thus, finally, they are able to create knowledge by themselves. This is regarded as sustainable learning (Institute for the Promotion of Teaching Science and Technology, 2003).

Several studies have been conducted by researchers in Thailand related to the CIPPA instructional model, for example research with the subject of students in Prathom Suksa 4, semester 1, the Academic year 2018, Suan Sunandha Rajabhat University Demonstration School (Camhongsa \& Youpensuk, 2020), research on the feasibility and suitability of e-learning learning designs using learning strategies (In-saard, 2013), learning achievement in the course politics, economy and society (Boonklum, 2015), dan learning result of innovation and information technology in education third year students in the Bachelor of Education Program (Hanrin, 2014). Other researchers developed a child-centered instruction module based on the CIPPA instructional model (Swekwi \& Songkampol, 2019), develop and investigate the efficiency of the mathematics instructional packages using CIPPA instructional model (Plerin, 2011), effectiveness in reducing students' anxiety in English writing classes (Thepwan, 2015), Thai literature learning achievement and attitude of students (Chandai, 2017), and student's achievement of learning process of hand washing to prevent the communicable diseases (Balsong \& Balsong, 2014), and learning achievement in science learning area of students (Bundasak, 2015).

Based on a review of various previous researches, there has been no research related to the CIPPA instructional model in biology for health sciences learning, especially with the subject of nursing students. Several applications of the CIPPA instructional model in science learning are carried out at the secondary school level. Meanwhile, there are no studies that compare or link the CIPPA instructional model with inquiry-based learning.

From the problems mentioned above, including the advantages of inquiry-based learning and the CIPPA instructional model, researcher as a biology course instructor for health sciences appreciated the importance of comparing academic achievement and scientific attitudes of first year nursing students. The purpose of this research was observing the effect of CIPPA instructional model on nursing students' scientific achievement and attitude. The research results will be used as guidelines for determining the most appropriate and effective teaching methods for further development of teaching and learning for nursing students.

\section{METHOD}

\section{Type of research}

This research was a quasi-experimental research in the classroom. The content of this research is in NS1102 Biology for Health Sciences. The topics was the structure and function of cells, cell division, and chemical reactions in cells. Researcher studied the 2 experimental groups by testing before and after the experiment. (Pretest-posttest design with nonequivalent group according to the research methodology of Cook and Campbell (1979). 


\section{Population and samples}

The population in this research was 110 students who are in the first year of nursing students at Pathumthani University for the first semester of academic year 2019. The samples were clustered (Cluster Random Sampling) including first year nursing students group 1 and 2, then easily randomized to select the room for the experiment. There were 55 of first year nursing students in group 1 , learning through inquiry method and other 55 students in group 2, and learning through management by CIPPA instructional model.

\section{Instrument and procedures}

The Research tools include 3 Inquiry Method learning plans (2-3 hours per plan, total 12 hours) and 3 CIPPA learning plans (2-3 hours per plan, total 12 hours). The collected data included the achievement test in Biology for Health Science with 4 multiple-choice totaling 80 questions with IOC of $0.65-1.00$. The reliability of the achievement test was done using KR-20 (Kuder Richardson - 20). The result showed that the classification power (r) was $0.20-0.64$ and the difficulty (p) was $0.45-0.80$. Science attitude test of students were used to measure 8 scientific attitudes, consisting of curiosity, reasoning, not being quick to draw conclusions, open-mindedness, and use of critical thinking, orderliness and prudence, honesty, responsibility and perseverance. The scientific attitude test, a measure of Likert's method value, was in the form of positive messages and negative messages in 32 items with $\mathrm{IOC}$ values between $0.67-1.00$.

\section{Data analysis}

The data analysis technique used the t-test analysis (Independent Sample t-test) to analyze the comparison of academic achievement of students learning through the inquiry method and the group that received CIPPA. Analysis of scientific attitude of students characteristic was a rating scale of 5 levels by analyzing the mean value and standard deviation.

\section{RESULTS AND DISCUSSION}

The result of scientific achievement data analysis of the students' learning through inquiry method and students' learning through CIPPA was presented in Table 1.

Table 1. Summary of scientific achievement data analysis comparison of the students' learning through inquiry method (control class) and students' learning through CIPPA (experiment class)

\begin{tabular}{lccccccc}
\hline Scientific achievement & $\mathbf{N}$ & Mean & S.D. & $\boldsymbol{\alpha}$ & $\mathbf{t}$ & Sig. & Description \\
\hline $\begin{array}{l}\text { Control CLASS } \\
\text { (Inquiry method) }\end{array}$ & 55 & 50.08 & 1.45 & 0.05 & -0.42 & 0.81 & $\begin{array}{c}\text { There is no } \\
\text { significant } \\
\begin{array}{l}\text { Experimental class } \\
\text { (CIPPA) }\end{array}\end{array}$ \\
\hline
\end{tabular}

Based on the result of data analysis presented in Table 1, it showed no difference in students' scientific achievement between two studied groups. This may be due to the process of organizing inquiry-based learning activities considered as another activity that is student-centered which helps to encourage students to study and understand the lesson by themselves. Meanwhile, the CIPPA teaching and learning is a principle that can be used as a guideline in biology teaching.

To find out the difference in means of the test result between experimental class and control class, t-test was conducted. Based on the data presented in Table 2, the significant value 0.313 was greater than the $\alpha$ value $(0.05)$, it can be concluded that there was a difference in the test result between the students' learning through inquiry method (control class) and students' learning through CIPPA (experimental class). In conclusion, it can be said that the CIPPA instructional method affected students' scientific attitude of the experimental class.

Table 2. Summary of data analysis comparison of scientific attitude of students' learning through inquiry method (control class) and students' learning through CIPPA (experimental class)

\begin{tabular}{lccccccc}
\hline Scientific attitude & $\mathbf{N}$ & Mean & S.D. & $\mathbf{t}$ & $\boldsymbol{\alpha}$ & Sig. & Description \\
\hline $\begin{array}{l}\text { Control class } \\
\text { (Inquiry method) }\end{array}$ & 55 & 89.07 & 4.63 & 1.12 & 0.05 & 0.313 & $\begin{array}{l}\text { There is a } \\
\text { significant } \\
\begin{array}{l}\text { Experimental class } \\
\text { (CIPPA) }\end{array}\end{array}$ \\
\hline
\end{tabular}


Based on the result of data analysis presented in Table 3 and Figure 1, it can be seen that the experimental class (CIPPA) have higher percentage level than the control class (Inquiry Method) in all. The highest scientific attitude when considering each item was perseverance and responsibility but the lowest was rationality

Table 3. Summary of data analysis comparison of Scientific Attitude of students' learning through inquiry method (control class) and students' learning through CIPPA (experimental class)

\begin{tabular}{|c|c|c|c|c|c|c|}
\hline \multirow{3}{*}{ Class } & \multicolumn{6}{|c|}{ Percentage of Scientific Attitude (\%) } \\
\hline & A & B & $\mathrm{C}$ & D & $E$ & $\mathbf{F}$ \\
\hline & $\begin{array}{l}\text { Perseverance and } \\
\text { responsibly }\end{array}$ & Curiously & Honesty & $\begin{array}{l}\text { Participating in opinions } \\
\text { and accepting opinions }\end{array}$ & Rationality & $\begin{array}{c}\text { Open- } \\
\text { mindedness }\end{array}$ \\
\hline $\begin{array}{l}\text { Control class } \\
\text { (Inquiry method) }\end{array}$ & $\begin{array}{l}69.8 \\
\text { Good }\end{array}$ & $\begin{array}{l}62.7 \\
\text { Good }\end{array}$ & $\begin{array}{c}47.5 \\
\text { Enough }\end{array}$ & $\begin{array}{c}53.1 \\
\text { Enough }\end{array}$ & $\begin{array}{l}29.2 \\
\text { Poor }\end{array}$ & $\begin{array}{c}49.6 \\
\text { Enough }\end{array}$ \\
\hline $\begin{array}{l}\text { Experimental } \\
\text { class (CIPPA) }\end{array}$ & $\begin{array}{c}89.3 \\
\text { Very Good }\end{array}$ & $\begin{array}{c}72.4 \\
\text { Very Good }\end{array}$ & $\begin{array}{l}80.8 \\
\text { Very Good }\end{array}$ & $\begin{array}{c}77.1 \\
\text { Very Good }\end{array}$ & $\begin{array}{l}57.4 \\
\text { Good }\end{array}$ & $\begin{array}{l}63.3 \\
\text { Good }\end{array}$ \\
\hline
\end{tabular}

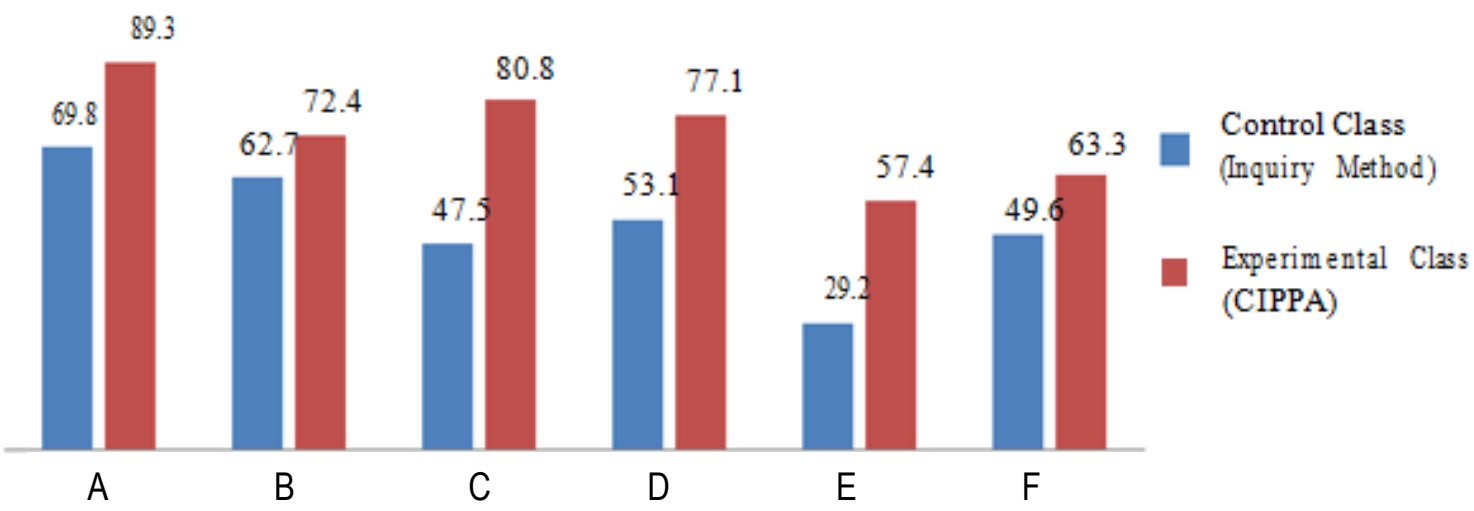

Figure 1. Graph of students' feelings or practices regarding scientific attitude

The data analysis presented in Table 1, the result showed no difference in students' scientific achievement between two studied groups. This may be due to the process of organizing inquiry-based learning activities considered as another activity that is student-centered which helps to encourage students to study and understand the lesson by themselves while the CIPPA teaching and learning is a principle that can be used as a guideline in biology teaching.

The results of this study are in line with several previous studies that have shown the positive impact of the CIPPA instructional model on students' scientific achievement. The application of the CIPPA instructional model to the 3rd year students of the Bachelor of Education Program shows that this model can improve learning achievement and satisfaction (Hanrin, 2014). In addition, the application of the CIPPA instructional model to the ninth graders students shows that the learning achievement of students were higher than those of the students taught with the conventional method (Hengchaiyo, 2017). The same results were also obtained in the subject of students in Prathom 4, Suan Sunandha Rajabhat University Demonstration School (Camhongsa \& Youpensuk, 2020). In addition, at the elementary school students level in the aspect of "how to wash hands to prevent disease", the application of the CIPPA instructional model provides high learning achievement results (Balsong \& Balsong, 2014). Thus, it can be said that the CIPPA instructional model is equivalent to a model commonly used in the world, namely the inquiry method. The inquiry method itself has been recognized as supporting students' scientific achievement, in this case, for example, as reported by several experts. Acar (2014) reported that there were scientific reasoning, situational knowledge, and achievement differences between the two groups at the beginning of instruction. Wen et al (2020) reports that results indicate that a guided inquiry learning environment can support students with different levels of school science achievement to highly engage in science inquiry. Yuliati, Parno, Yogismawati, and Nisa (2018) also reported that the inquiry method influences the scientific literacy and concept achievement of physics.

The result was consistent with the research of Pawong (2005) who had studied and compared the learning achievement in science and interaction of secondary school students who had been taught by CIPPA and the search for knowledge and there was no difference shown. Buaprai (2009) studied CIPPA instructional model by comparing learning achievement before and after learning found that after the students had received CIPPA, they had higher academic achievement. Chinda and Thepwan (2015) studied the effectiveness of the CIPPA instructional model in reducing students' anxiety in English writing classes. The results of the study reveal that 
after the CIPPA based learning activities, the students' anxiety in English writing class reduced significantly at a statistical level of.05. It was also found that the anxiety in relation to the students themselves reduced the most, followed by the anxiety regarding the teacher and the anxiety in respect to the students' classmates respectively. In addition, collectively, the students' satisfaction with the CIPPA instructional model were at a high level. More to the point, to put the students' satisfaction in order from highest to lowest, they were pleased with learning contents, assessment and evaluation, learning materials and resources, and teaching and learning activities respectively. Other research on the course politics, economy and society was conducted by Boonklum (2015) has shown that the learning achievement results of the sample group instructed based on the CIPPA instructional model in Semester 2/2014 were significantly higher than those of the students instructed in a control classroom.

The scientific attitude test result between experimental class and control class, t-test was conducted. Based on the data presented in Table 2, it can be concluded that there was a difference in the test result between the students' learning through inquiry method (control class) and students' learning through CIPPA (experimental class). CIPPA have higher percentage level than inquiry method. In conclusion, it can be said that the CIPPA instructional method affected students' scientific attitude of the experimental class.

Thus, it can be said that the CIPPA instructional model is equivalent to a model commonly used in the world, namely the inquiry method. The inquiry method itself has been recognized as supporting students' scientific achievement, in this case, for example, as reported by several experts. The above result was consistent with the research of Suphon (2013) conducted research on how CIPPA instructional model affected the academic achievement and scientific attitude. There was no significant difference between the database system course at the statistically significant level of 0.05 . On the contrary, it found that scientific attitudes in the form of perseverance, responsibility as for the opinions and acceptance and the reasoning of students in the population group had changed for the better. As also reported by Hengchaiyo (2017) that the scientific attitudes in ninth graders students who got the application of the CIPPA instructional model were higher than those of the students taught with the conventional method.

However, although in this study CIPPA is better than the inquiry method (which has become "globalized") in increasing the scientific attitude, it must be understood that much research is still needed in the future. We still understand that the inquiry method is still one of the most widely used and proven methods for increasing the scientific attitude as we have found many reports in various publications (Cho \& Woo, 2017; Dewi, Saputri, Nurkhalisa, \& Akhlis, 2020; Hastuti, Nurohman, \& Setianingsih, 2018; Mayangsari, Yusrizal, \& Mustafa, 2020; Rohaeti, Prodjosantoso, \& Irwanto, 2020; Smit et al., 2017; Vácha \& Rokos, 2017; Wildan, Hakim, Siahaan, \& Anwar, 2019). At a minimum, we can understand that the CIPPA instructional model has the same potential success as the inquiry method.

\section{CONCLUSION}

Based on the data analysis result and discussion, it showed that CIPPA instructional model affected scientific achievement and scientific attitude of nursing students in the experimental class. This teaching method can be applied to teach biology. The suggestion for next research is that additional data should be collected through interviews or group discussions with students about the learning process in order to be used as in-depth feature information for experimental studies to gain useful details for improving the instructional management by using CIPPA instructional model.

\section{ACKNOWLEDGEMENT}

The author's acknowledgement was conveyed for several parties who were involved in this research, namely, all professor of Department of Biology Srinakharinwirot University and the all professors and nursing students for the first semester of academic year 2019 of Faculty of Nursing at Pathumthani University. Thank you for your cooperation in this research.

\section{REFERENCES}

Acar, Ö. (2014). Scientific reasoning, conceptual knowledge, \& achievement differences between prospective science teachers having a consistent misconception and those having a scientific conception in an argumentation-based guided inquiry course. Learning and Individual Differences, 30, 148-154. doi: https://doi.org/10.1016/j.lindif.2013.12.002 
Afgan, N. H., \& Carvalho, M. G. (2010). The knowledge society: A sustainability paradigm. Cadmus, 1(1), 2841. Retrieved from https://www.cadmusjournal.org/node/14

Almeida, L. da S., \& Franco, A. H. R. (2011). Critical thinking: Its relevance for education in a shifting society. Revista de Psicología, 29(1), 175-195. Retrieved from http://pepsic.bvsalud.org/scielo.php?script=sci_ arttext\&pid=S0254-92472011000100007

Ariratana, W. (2010). The development of learning management model focusing on thinking skills in the basic education curriculum, B. E. 2544. International Journal of Education, 33(1), 25-30. Retrieved from https://www.tci-thaijo.org/index.php/EDKKUJ/article/download/50171/41560

Balsong, S., \& Balsong, A. (2014). The affect of Child-centered Instruction by CIPPA Model on the student 's achievement of learning process of hand washing to prevent the communicable diseases in Sornthipaya Kindergarten Buriram Province Sima Balsong, Adisorn Balsong Abstract. Retrieved from https://www. researchgate.net/publication/210359523

Boonklum, N. (2015). The development of the learning achievement in the course politics, economy and society using CIPPA model instruction. Veridian E-Journal, Silpakorn University, 8(5), 1-18. Retrieved from https://he02.tci-thaijo.org/index.php/Veridian-E-Journal/article/view/45412/37585

Buaprai, R. (2009). The study of instructional management by using the model teaching and learning model CIPPA affecting the academic achievement and scientific attitude of Mathayom Suksa one students 1. Bangkok.

Bundasak, M. (2015). The learning outcome of using CIPPA model integrated with local wisdom in the pottery of Koh Kret community in Nonthaburi province towards the learning achievement in science learning area of students in Prathomsuksa 3 (Dhonburi Rajabhat University). Retrieved from http://cms.dru.ac.th/jspui/ bitstream/123456789/144/1/title1.pdf

Camhongsa, N., \& Youpensuk, N. (2020). A comparison of learning achievement using CIPPA model for grade 4 students of demonstration school of Suan Sunandha Rajabhat University, Bangkok, Thailand. The 2020 International Academic Multidisciplines Research Conference in Lucerne, 240-245. Retrieved from http://icbtsproceeding.ssru.ac.th/index.php/ICBTSLUCERNE2020/article/view/510/504

Carrillo, F. J. (2015). Knowledge-based development as a new economic culture. Journal of Open Innovation: Technology, Market, and Complexity, 1(2), 1-17. doi: https://doi.org/10.1186/s40852-015-0017-5

Chandai, S. (2017). Effects of using CIPPA instructional model integrated with literature learning process on learning achievement and attitude toward Thai literature of lower secondary school students in the demonstration school (Chulalongkorn University). Retrieved from http://cuir.car.chula.ac.th/dspace/ handle/123456789/53202

Chinda, B., \& Thepwan, W. (2015). Effectiveness of the CIPPA instruction model in reducing students' anxiety in English writing classes. Chiang Mai.

Cho, J., \& Woo, A. J. (2017). A study on the understanding about nature of scientific knowledge and attitude toward scientific inquiry of pre-service science teacher through open inquiry. Journal of the Korean Chemical Society, 61(5), 263-276. doi: https://doi.org/10.5012/jkcs.2017.61.5.263

Combi, M. (2016). Cultures and technology: An analysis of some of the changes in progress- Digital, global and local culture. In K. J. Borowiecki, N. Forbes, \& A. Fresa (Eds.), Cultural Heritage in a Changing World (pp. 3-15). doi: https://doi.org/10.1007/978-3-319-29544-2_1

Cook, T. D., \& Campbell, D. T. (1979). Quasi-experimentation: Design \& analysis issues for field settings. Retrieved from https://books.google.co.id/books/about/Quasi_experimentation.html?id=BFNqAAAAMAA J\&redir_esc=y

Dewi, N. R., Saputri, E., Nurkhalisa, S., \& Akhlis, I. (2020). The effectiveness of multicultural education through traditional games-based inquiry toward improving student scientific attitude. Journal of Physics: Conference Series, 1567, 042051. doi: https://doi.org/10.1088/1742-6596/1567/4/042051

Dufva, T., \& Dufva, M. (2019). Grasping the future of the digital society. Futures, 107, 17-28. doi: https://doi.org/ 10.1016/j.futures.2018.11.001

Garcia, E. S. (2000). Science and technology and their role in human health in developing countries. Memórias Do Instituto Oswaldo Cruz, 95(Suppl. 1), 5-7. doi: https://doi.org/10.1590/s0074-02762000000700001

Hanrin, C. (2014). Development of the learning result of innovation and information technology in education using CIPPA, for third year students in the Bachelor of Education Program, Nakhon Phanom University. Research in Higher Education Journal, 22, 1-10. Retrieved from http://search.ebscohost.com/login.aspx? direct=true\&db=eric\&AN=EJ1064105\&scope=site

Hastuti, P. W., Nurohman, S., \& Setianingsih, W. (2018). The development of science worksheet based on 
inquiry science issues to improve critical thinking and scientific attitude. Journal of Physics: Conference Series, 1097, 012004. doi: https://doi.org/10.1088/1742-6596/1097/1/012004

Hengchaiyo, J. (2017). Science learning achievement and attitudes of the ninth graders students learning through the CIPPA model. Journal of Lanna Academic Affairs, 8(1), 40-48. Retrieved from https://www.tci-thaijo.org/index.php/EDKKUJ/article/download/50171/41560

In-saard, S. (2013). PSPSKAPE instructional strategy for enhancing knowledge construction of learners in the 21ST century. Proceedings of ICERI2013 Conference, (November), 4495-4503. Retrieved from http:// www.edu.ru.ac.th/et-ram/techno/images/pdf/e227.pdf

Ingthorsson, R. D. (2013). The natural vs. the human sciences: Myth, methodology and ontology. Discusiones Filosóficas, 14(22), 25-41. Retrieved from http://ref.scielo.org/36kny8

Institute for the Promotion of Teaching Science and Technology. (2003). Science evaluation guide. Bangkok: IPTST. Retrieved from http://eng.ipst.ac.th/

Klinbumrung, K., Tansriwong, S., \& Akatimagool, S. (2015). The development of instructional package on highfrequency transmission line engineering using REPEA learning model. The 3rd International Conference on Technical Education, 19-22. Retrieved from http://ncteched.fte.kmutnb.ac.th/nc8/ICTechEd03/ICTech ED03EDU05.pdf

Mayangsari, F., Yusrizal, \& Mustafa. (2020). Application of guided inquiry learning model to improve students' scientific attitudes and learning outcomes. Journal of Physics: Conference Series, 1460, 012138. https:// doi.org/10.1088/1742-6596/1460/1/012138

Pawong, S. (2005). A comparison of academic achievement in science and interaction of Lower secondary school students taught by the CIPPA and the inquiry. Chiang Mai.

Phillips, F., Yu, C.-Y., Hameed, T., \& El Akhdary, M. A. (2017). The knowledge society's origins and current trajectory. International Journal of Innovation Studies, 1(3), 175-191. doi: https://doi.org/10.1016/j.jijs. 2017.08.001

Plerin, K. (2011). Development of the mathematics instructional packages using CIPPA model on the power number for Mathayom Suksa 1 (Sakon Nakhon Rajabhat University). Retrieved from https://gsmis.snru. ac.th/e-thesis/file_att1/20191001512B93137_fulltext.pdf

Ramirez, J. M., \& Cayón-Peña, J. (2017). The role of scientists in a human-centered society. Cadmus, 3(2), 113-130. Retrieved from https://libez.lib.georgiasouthern.edu/login?url=https://search.ebscohost.com/ login. aspx?direct=true\&db=edb\&AN=124313394\&site=eds-live

Rohaeti, E., Prodjosantoso, A. K., \& Irwanto, I. (2020). Research-oriented collaborative inquiry learning model: Improving students' scientific attitudes in general chemistry. Journal of Baltic Science Education, 19(1), 108-120. doi: https://doi.org/10.33225/jbse/20.19.108

Sellars, M., Fakirmohammad, R., Bui, L., Fishetti, J., Niyozov, S., Reynolds, R., ... Ali, N. (2018). Conversations on critical thinking: Can critical thinking find its way forward as the skill set and mindset of the century? Education Sciences, 8(4), 205. doi: https://doi.org/10.3390/educsci8040205

Severinghaus, J. W. (2014). The most important application of science. EMBO Reports, 15(9), 919-922. doi: https://doi.org/10.15252/embr.201438848

Smit, R., Weitzel, H., Blank, R., Rietz, F., Tardent, J., \& Robin, N. (2017). Interplay of secondary pre-service teacher content knowledge (CK), pedagogical content knowledge (PCK) and attitudes regarding scientific inquiry teaching within teacher training. Research in Science and Technological Education, 35(4), 477499. doi: https://doi.org/10.1080/02635143.2017.1353962

Spector, J. M., \& Ma, S. (2019). Inquiry and critical thinking skills for the next generation: from artificial intelligence back to human intelligence. Smart Learning Environments, 6(8), 1-11. doi: https://doi.org/ 10.1186/s40561-019-0088-z

Suphon, N. (2013). The teaching model is the CIPPA model: Affecting the academic achievement and scientific attitude. Chiang Mai.

Swekwi, U., \& Songkampol, N. (2019). Child-centered instruction module: CIPPA Model. Ratchaphruek Journal, 17(2), 1-13. Retrieved from https://so05.tci-thaijo.org/index.php/Ratchaphruekjournal/article/view/1609 $70 / 135126$

Tal, T., \& Dierking, L. D. (2014). Learning science in everyday life. Journal of Research in Science Teaching, 51(3), 251-259. doi: https://doi.org/10.1002/tea.21142

The Ministry of Education of Thailand. (2008). The basic education core curriculum B.E. 2551 (A.D. 2008). Retrieved from http://www.act.ac.th/document/1741.pdf

The Ministry of Education Thailand. (2001). Basic education curriculum B. E. 2544 (A.D. 2001 ). Bangkok: 
Department of Curriculum and Instruction Development.

Thepwan, W. (2015). Effectiveness of the CIPPA instruction model in reducing students' anxiety in English writing classes (Chiang Mai University). Retrieved from http://cmuir.cmu.ac.th/handle/6653943832/39735

Thita, S., \& Ariya, K. (2020). The local context-based instructional model of the 21st-century career skills development for primary students in Chiangrai. RSU International Research Conference 2020, (May), 1011-1019. Retrieved from https://rsucon.rsu.ac.th/files/proceedings/inter2020/IN20-002.pdf

Uluçınar, U., \& Arı, A. (2019). The development of caring thinking skills inventory based on problem scenarios: A study of validation and reliability. Universal Journal of Educational Research, 7(6), 1414-1429. doi: https://doi.org/10.13189/ujer.2019.070609

Vácha, Z., \& Rokos, L. (2017). Integrated science and biology education as viewed by Czech university students and their attitude to inquiry-based scientific education. New Educational Review, 47(1), 243-252. doi: https://doi.org/10.15804/tner.2017.47.1.19

Vali, I. (2013). The role of education in the knowledge-based society. Procedia - Social and Behavioral Sciences, 76, 388-392. doi: https://doi.org/10.1016/j.sbspro.2013.04.133

Wang, C. (2018). Scientific sulture and the construction of a world leader in science and technology. Cultures of Science, 1(1), 1-13. doi: https://doi.org/10.1177/209660831800100102

Wen, C. T., Liu, C. C., Chang, H. Y., Chang, C. J., Chang, M. H., Fan Chiang, S. H., ... Hwang, F. K. (2020). Students' guided inquiry with simulation and its relation to school science achievement and scientific literacy. Computers and Education, 149, 103830. doi: https://doi.org/10.1016/j.compedu.2020.103830

Wildan, W., Hakim, A., Siahaan, J., \& Anwar, Y. A. S. (2019). A stepwise inquiry approach to improving communication skills and scientific attitudes on a biochemistry course. International Journal of Instruction, 12(4), 407-422. doi: https://doi.org/10.29333/iji.2019.12427a

Yuliati, L., Parno, P., Yogismawati, F., \& Nisa, I. K. (2018). Building scientific literacy and physics problem solving skills through inquiry-based learning for STEM education. Journal of Physics: Conference Series, 1097, 012022. doi: https://doi.org/10.1088/1742-6596/1097/1/012022 